\title{
Developing sub-acute and non-acute Casemix classification: the Thailand experience
}

\author{
Supasit Pannarunothai \\ From The 6th International Casemix Conference 2012 (6ICMC2012) \\ Kuala Lumpur, Malaysia. 6-7 June 2012
}

\section{Background}

The needs for other modes of care apart from acute hospital care have long been realized but minimal integrated efforts have developed so far. Payment mechanism is a strong financing strategy to create favorable changes in the health systems.

\section{Objective}

This session is to illustrate the rationale and progress of the developments of sub-acute and non-acute Casemix classification as a financing mechanism in Thailand.

\section{Method}

Review of literature of the last five years is the main data collection.

\section{Result}

The rehabilitative medicine has been an established discipline for over four decades in Thailand while psychiatry even longer. Complaints from health care providers of being underfunded activities have been around since the third revision of Thai Diagnosis Related Group since 2001. The fifth revision of TDRG set the goal of accomplishing other Casemix classifications apart from DRG for acute inpatient care, two Casemix systems for inpatient psychiatric and rehabilitative care were submitted to the National Health Security Office in 2011. The NHSO anticipated the difficulties of implementing the two new Casemix systems as initiative payment methods. Two separate streams of putting the Casemix products to the health systems were designed. Further follow-ups of these developments are needed to document knowledge generation related to health system outcomes via financing initiatives.

Centre for Health Equity Monitoring, Faculty of Medicine, Naresuan University, Thailand

\section{Conclusion}

Health finance and Casemix research need long-term commitment of a development team to refine results to find ways of implementing into health systems as well as to evaluate whether favorable changes happen.

Published: 21 November 2012

\section{doi:10.1186/1472-6963-12-S1-14}

Cite this article as: Pannarunothai: Developing sub-acute and non-acute Casemix classification: the Thailand experience. BMC Health Services Research 2012 12(Suppl 1):14. and take full advantage of:

- Convenient online submission

- Thorough peer review

- No space constraints or color figure charges

- Immediate publication on acceptance

- Inclusion in PubMed, CAS, Scopus and Google Scholar

- Research which is freely available for redistribution 